\title{
THE PROBLEMS AND UTILIZATION OF CREDITS AND THEIR EFFECT ON THE INCOME OF OIL PALM FARMERS IN MUSI BANYUASIN REGENCY OF INDONESIA
}

\author{
Sabrina Leni, Yazid Muhammad*, Maryadi \\ Master Program in Agribussiness, Faculty of Agriculture, University of Sriwijaya, Indonesia \\ *E-mail: yazid ppmal@yahoo.com
}

\begin{abstract}
Agricultural financing is one of the neccesary components for the development of oil palm as one of the main commodities in Musi Banyuasin Regency, Indonesia. This research aimed to investigate the financial problems faced by oil palm farmers, describe the utilization of credit provided by the banks, and analyze the influence of credit and other factors on the income of oil palm farmers. A sample of 120 farmers were selected using disproportionate stratified random sampling method. The results showed that several problems still existed in the budgeting of oil palm plantation in the study area, among these the inavailability of credits was the highest contributor to problems. However, among farmers received credits from the financial institutions, most of the credit was effectively used for oil palm related expenditures. Statistical analysis indicated that the amount of credit received, the credit instalment and the area of oil palm significantly affected the income of oil palm farmers in the study area. It was suggested that credits from formal financial institution should be widely made available for oil palm farmers such that they can increase the area of plantation and income.
\end{abstract}

\section{KEY WORDS}

Credit, oil palm, farmers, income.

South Sumatera province, according to the agricultural, forestry, and fishery sectors, contributes toward the Gross Regional Domestic Products (GRDP) on current price as much as $16,06 \%$. Contribution of this sector is the second after mining and excavating sectors. However, the contribution of agricultural sector toward the GRDP continues to decline in the last 5 years. Sub-sector of plantation is the greatest contributor toward the agricultural sector as much as $31,36 \%$ of the entire agricurtural, forestry, and fishery (BPS, 2016).

Based on the considerable contribution of GRDP in agricultural sector in South Sumatera Province, therefore South Sumatera has great economy and able to support the Indonesian development. Yet, this great potency has not been able to increase the welfare of the South Sumatera farmers. This is caused by various problems faced by the agricultural sector such as the large number of poor farmers, low level of education, and the continous reduction of farm field. Another problem identified as a major problem is the limited access to financial service. Thefore, limited capital becomes a weakness of farmers (Rizieq, 2010). Farmers' limitation to finance their work causes the current productivity is lower than the potential productivity. In addition, agricultural sector is the sector considered to possess high risk, a situation in which some factors can not be controlled that cause unexpected result for the farmers (Wahyudi, 2011). The existence of budgeting resource in form of credit is very neccesary in developing the productivity in agricultural sector, mainly to small farmers. The availability of adequate budgeting can create capital establishment for the farming that may increase production and income which in turn can be utilized to pay back the credit. National banking theoretically has great potential as one of the budgeting resources in agricultural sector. This institution has core bussiness to collect fund from the society and to dispense it to the businesses in form of credit or budgeting (Ashari, 2009). Yet, the fact shows that the national banking tends not quite enthusiastic to dispense credit for agricultural sector.

The regional economics and finance study of South Sumatera Province (February 2017) shows that the slow growth of credit in agricultural, forestry, and fishery sectors were as much as $5,2 \%$ which is really far compared to that of the manufacture and industrial 
sector as much as $39,26 \%$, the accomodation and food provider sector as much as $31,17 \%$, and construction sector as much as $24,75 \%$ (Bank of Indonesia, 2017). Generally the formal financial institution has not shown adequate support to agricultural sector. The lowness of the credit development in this sector is due to the high interest. This can be seen from the development avarage of interest in the agricultural and plantation sector as much as $2,07 \%$, a bit lower than the mining and excavating sector as much as 2,57\% (Agricultural Ministry, 2016). This is one of the causes of low credit allocation in agricultural sector since there has been no specific treatment from budgeting institutions for agricultural sector. So far, the policy for the agricultural budgeting has been integrated to the non agricultural budgeting with the result that this sector is not competitive. This underlies the importance of the research to investigate the problems and the budgeting utilization faced by the farmers and to analize what credit factors that influence the palm fruit farmers' income in Musi Banyuasin Regency, Indonesia.

\section{METHODS OF RESEARCH}

This research was conducted in South Sumatera Province, the location was purposively determined with a consideration that South Sumatera Province was one of the centrals of financial dispense of for agricultural sectors in the working areas of banking in South Sumatera Province. Musi Banyuasin Regency as selected as the research area since it has been the biggest budgeting dispense for the agricultural sector according to the Bank of Indonesia (2017). This regency is expected to represent some regencies or cities in South Sumatera Province. Within this regency, a subdistrict which is the sentral of oil palm plantation namely Subdistrict Sungai Lilin. Within this subdistrict, a village was chosen to become the research area. This research employed a survey method. The data consisted of primary and secondary data. The primary data were collected by conducting direct interview with the sample farmers using questionnaires. Secondary data were collected from institutions related to the research such as Bank of Indonesia, Central Agency of Statistics, Regency Office of Agriculture, and other instances that could support the research. The population of the research was the farm households which cultivated oil palm who received credit from conventional and syariah financial institution as many as 841 houses. The samples of 120 farm households were selected using cluster sampling.

Based on the theoritical observation, to investigate the problems faced by the farmers in budgeting utilization, the data collected were tabulated and descriptively analyzed. Meanwhile, to analyze the credit factors that influenced the oil palm farmers' income, an ordinary least square method was employed based on the following equation:

$$
Y=a+b_{1} X_{1}+b_{2} X_{2}+b_{3} X_{3}+b_{4} X_{4}+b_{5} X_{5}+b_{6} X_{6}+e
$$

Where: $Y=$ Income of farmers; $\alpha=$ Constant; $b_{1-6}=$ Parameters; $X_{1}=$ Credit received by the farmers; $X_{2}=$ Credit instalment; $X_{3}=$ Credit period; $X_{4}=$ Land area owned; $X_{5}=$ Age; $\mathrm{X}_{6}=$ Education; $\mathrm{e}=$ Residual.

\section{RESULTS AND DISCUSSION}

The establishment of the capital aims to increase the production and income of farmers and to enable further establishment of the capital (Soekartawi, 1986). Until recently, limited capital has been becoming constraint to agricultural development, espacially in oil palm farming.

The result showed that problems related to budgeting in oil palm farming were: (a) inavailability of financial resources, (b) interest rate remain high, (c) limited amount of money that can be borrowed, (d) considerable reduction of capital upon approval, (e) poor service, (f) difficulties in obtaining the credits, and $(\mathrm{g})$ the process was time-consuming. Among these problems, inavailability of financial source experienced by farmers accounted the highest (Figure 1). 


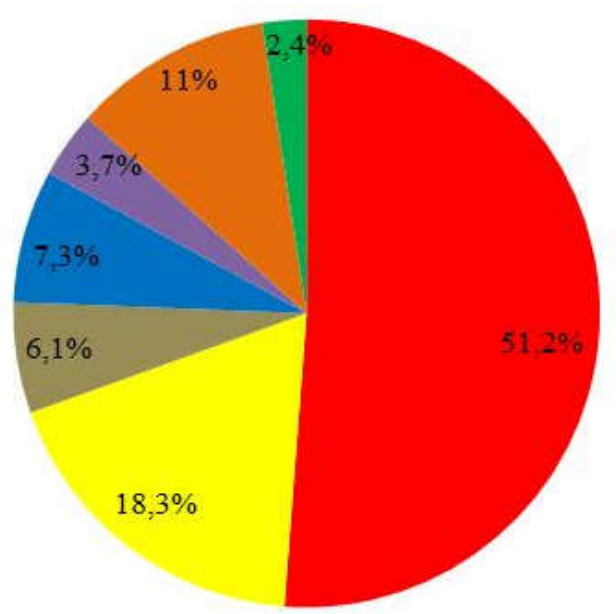

\author{
- Inavailability of financial resources \\ Interest rate remain high \\ = Limited amount of money that can be \\ borrowed \\ - Considerable reduction of capital upon \\ approval \\ a Poor service \\ Difficulties in obtaining the credits \\ - The process was time-consuming
}

Figure 1 - Distribution of sample farmers accoording to problems faced in budgeting

The second purpose, the assessment of the utilization of capital gained from the bank, indicated that most of the capital (97.5 percent) was used for oil palm cultivation. This high percentage indicated that the fund has been effectively utilized according to the purpose of the fund. The rest of the fund was used for other needs such as to complement the capital for bird nest farming, local shop selling daily needs, daily haousehold expenditure, and school fee for children.

The third objective, the effect of factors related to credit on the income of farmers was analyzed using linear regression. Prior to the analysis, all assumptions for regression (normality of error, have been checked and proved to fulfill the assumptions. The result of analysis were shown in Table 1.

Table 1 - Results of Regression Analysis

\begin{tabular}{|l|l|l|l|l|}
\hline Variables & Coefficient & Std. Error & $\mathrm{t}$ & Sign. \\
\hline Constant & 2133063.466 & 350893.247 & 6.079 & .000 \\
\hline Amount of credit received & .008 & .002 & 3.242 & .002 \\
\hline Credit instalment & .564 & .087 & 6.471 & .000 \\
\hline Credit period & -4575.349 & 4656.757 & -.0983 & .328 \\
\hline Land area & 261535.947 & 76220.622 & 3.431 & .001 \\
\hline Age & -1240.176 & 4942.494 & -.251 & .802 \\
\hline Education & -4950.886 & 15791.453 & -.314 & .754 \\
\hline F-test & 141.625 & & & \\
\hline Sig. of F-test & .000 & \multicolumn{5}{l|}{} \\
\hline R-square & .883 &
\end{tabular}

Dependent variable: Farmers' income.

The result indicated that the overall analysis (F-test) was significant statistically. The Rsquare of.883 explained that majority of variation in farmers' income can be explained by the independent variables simultaneously. Individual t-test proved that the independent variables related to credits (amount of credit received and credit instalment) were good predictors of farmers' income. In addition, land area was also a good predictor of farmers' income. Whereas, none of the individual variables were good predictors of oil palm farmers' income. The individual effect of the significant predictors are explained the subsequent parts.

The amount of credit received by oil palm farmers was a significant predictor of their income. The value of its coefficient indicated that every million Rupiah of the credit received by farmers would increase as much as Rp 8,000 of their monthly income. This was parallel with the Iski's research (2016) which explained the credit or budgeting used for the production activity could increse the production and income of farmers.

The credit instalment was also a significant predictor of oil palm famers' income. It positively affected the farmers' income inwhich every Rupiah increase in credit instalment will 
increase farmers' income as much as Rp.564. This indicated that the higher the credit instalment the higher the effort of farmers to increase their income.

Land area of oil palm was the only factor other than credit related factors that significantly affected the income of oil palm farmers. The effect of land area on the income was positif inwhich every additional hectare of oil palm will increase the monthly income of farmers by $\mathrm{Rp} 261,535$. This finding was parallel to that of Adriana's research (2015) which found that the land area influenced positively the income of oil palm farmers.

The effect of farmers' age on their income were not significant statistically. However, the effect of age was negative on the income since the older the farmers the less their willingness to take credit from the bank due to the apprehension to pay the instalment. This was parallel with the Anyiro's and Oriaku's research (2011) which discovered that age had negative coefficient in which the older farmers tended not take risk of using money from others such that they relied more on self capital. The influence of farmers' formal education on their income was also insignificant which meant formal education did not affect their income. Instead, informal education might had the effect on their ways of doing their business that might contribute positively on their income.

\section{CONCLUSION}

Oil palm farmers faced several problems related to budgeting of their plantation. Among these problems, the availability of credits contributed the highest to the budgeting problems.

However, for the farmers who had access to financial institutions, most of the capital gained from the institutions (mainly bank) was used for oil palm cultivation. This indicated that the fund has been effectively utilized.

Statistical analysis proved that among six independent variables assumed to affect the income of oil palm farmers, three of these were the significant predictors of the income. Amount of credit obtained, credit intalment, and land area had significant effect on the income. These three factors contributed positively to the income of oil palm farmers.

\section{REFERENCES}

1. Adriana, 2015. Pengaruh Kredit Modal Kerja BRI dan Luas Lahan Terhadap Pendapatan Usaha Petani Sayur Mayur di Kelurahan Malakaji Kecamatan Tompobulu Kabupaten Gowa. Skripsi. Universitas Islam Negeri Alauddin Makasar.

2. Anyiro, C.O., 2011. Access to and Invesment of Formal Micro Credit by Small Holder Farmers in Abia State, Nigeria. The Journal of Agricultural Sciences 6(2): 69-76.

3. Ashari. 2009. Peran Perbankan Nasional Dalam Pembiayaan Sektor Pertanian di Indonesia. Forum Penelitian Agro Ekonomi. Bogor.

4. Bank Indonesia, 2017. Kajian Ekonomi dan Keuangan Regional Provinsi Sumatera Selatan Februari 2017. Palembang.

5. Badan Pusat Statistik, 2016 Produk Domestik Regional Bruto Provinsi Sumatera Selatan Menurut Lapangan Usaha 2016.

6. Iski, N., 2016. Pengaruh Kredit Terhadap Pendapatan Petani Kopi Arabika di Kabupaten Aceh Tengah Provinsi Aceh. Jurnal Manajemen \& Agribisnis 13(2): 132-144.

7. Kementerian Pertanian, 2016. Statistik Makro Sektor Pertanian 2016. Jakarta: Kementan.

8. Rizieq, R., 2010. Analisis Dampak Kredit Pertanian Pada Pertumbuhan Sektor Pertanian dan Ekonomi. Jurnal Visis Ekonomi 9(2): 1412-8403.

9. Soekartawi, et al. 1986. IImu Usahatani dan Penelitian Untuk Pengembangan Pertanian. UI-Press, Jakarta.

10. Wahyudi, A.F., 2011. BMT untuk Sektor Pertanian. Jurnal Ekonomi Islam Republika. 